\title{
Fr. Jocopo Broy-A Missionary without a Mission.
}

\author{
Magdalyne Syiemlieh \\ Department of History, St.Mary's College, Shillong, India.
}

\begin{abstract}
The history of the Catholic Church in North East India was indeed the work of a number of pioneer missionaries who served and dedicated the cause of the gospel with great zeal and contributed substantially to its remarkable growth and development. The missionaries constituted a devoted and dedicated band drawn from every part of the world, and included men and women, priest and nuns as well as laity whose heroic missionary life, dedication and self service laid the foundation of a flourishing mission field. This paper is an attempt to study the role of the Milan Foreign Mission Society or PIME in the Assam Mission through their lone missionary Fr. Jocopo Broy who dedicated his life and service to Assam, inspite of many woes and trials, challenges and controversies and without any active support from his home mission or superiors. The fact that he singlehandedly manage the Assam mission for 18 long years is not without significance in the history of the Catholic Church in North East India and though he may be considered as a missionary without a formal mission, yet much credit goes to him for having convinced others after him that Assam was an ideal mission field which today has grown into a considerable community of faith with an inner dynamism of its own.
\end{abstract}

Keywords: Assam mission, Fr. Jocopo Broy, Milan Foreign Mission Society PIME.

\section{Introduction}

The earliest Catholic presence in North East India was in no way due to any planned missionary undertaking but in the form of a transitory phase since Tibet and China were the cherished goals of many a missionary expedition. In fact Assam was hardly known to the outside world except as an unpleasant region offering a passage to Tibet and China. Rangamati in Goalpara district of Assam and Bondashill (now in Bangladesh) are known to have the earliest presence of Catholic missionaries in North East India.

Though the entire North East of India had been under the jurisdiction of the Vicar Apostolic of Calcutta since its inception in 1834, Tibet however, since 1784 belonged to the Vicariate Apostolic of TibetHindustan with Agra as it head quarter. By 1846 due to Chinese opposition to the French missionaries entering Tibet through China, the Lhasa Vicariate was set up to allow the MEP missionaries to reach Tibet. By June 1850 two MEP missionaries- Frs. Rabin Krick and Bernard reach Guwahati from France. Though their main objective was to reach Tibet, they became involved to a certain extent with local work attending to the European Catholic resident in the Bramahputra valley, serving their spiritual need. In February 1854 Fr. Krick and a new missionary Fr. Bernard passed through the Mishmi territory and reached Tibet but were pursued and murdered by the Mishmi Chief Kaisa. Thus forcing the MEP to withdraw from Assam, which once again reverted to Calcutta and then Sikkim with a view to entering Tibet via Dibrugarh. Though Assam lies very close to the districts of Sylhet and Cachar which were in the Vicariate of East Bengal, yet the Brahmaputra valley was never attended to by the Catholic missionaries of Bengal on grounds of lack of personnel.

\section{Fr. Broy and the Mission of Central Bengal.}

Born in Venice in 1834, Fr. Jocopo Broy was ordained priest at the local seminary after completing his studies and soon took up the post of Director of the Institute at San Pietra di Castello (Venice) which looked after orphanage boys. The setting up of the Milan Foreign Mission Society or PIME as it was called in 1850, similar to the Paris Foreign Mission was based on the recommendation of Pope Pius IX, eventually brought Broy to India in 1866 to serve in the Mission of Central Bengal and then Assam.

Meanwhile in India in the early $19^{\text {th }}$ century the mission of Central Bengal had come under the influence of different Christian Missions and very often for the Catholics the question of providing resident Priest for bigger towns like Berhampore, Krishnagar and Jessore was a cause of great concern for them since there was no immediate solution to solve the problem. Pressed hard by the problem of shortages of priests, the Vicar Apostolic of West Bengal, Archbishop Carew in 1853 invited the Milan Foreign Mission to take over the Mission of West Central Bengal with Krishnagar as its head-quarter.

Though the need to raise Central Bengal into the status of a Prefecture and later to a Vicarate had been realised by both Rome and the Archbishop of Calcutta, however, due to lack of men and resources the plan could not materialise. Thus on being informed of the availability and willingness of the Milanese Missionaries for the Indian mission Archbishop Carew hurriedly accepted them for the mission of Central Bengal. By 
February 1855, four Milanese missionaries under Antonio Marietti as their Superior set out for Central Bengal and Hyderabad. In this way Marietti and a lay Cathechist Giovanni Sesana became the pioneers of Central Bengal mission.

Of the many reasons for PIME accepting the Indian mission of Central Bengal was the fact that "the Indian Mission were a favourable theme of the Romantic Missionary Literature of the period of Catholic renewal" since much had been highlighted of the great work of the MEP and the Jesuits in India. By 1866 three more Milanese missionaries arrived in Bengal with Jocopo Broy as one of them. On his arrival in Central Bengal he was posted at Berhampore which in the post Mutiny period had been transformed into a military cantonment accommodating many soldiers and their family. Thus Broy was appointed as Chaplain administering pastoral care to the soldiers and other Europeans living in the area and as a substitute priest for ailing and those who had left home. His field of activity was rather a limited one compared to what he would be called upon later.

\section{The Assam Mission.}

While taking note of the fact that many initial attempts to reach Assam with the gospel had failed and under pressure from the rising wave of Protestantism, the Apostolic Visitor Charbonneaux who visited India in 1869 suggested to Rome that Assam be taken away from the mission of East Bengal and be given to the charge of Central Bengal under the Milanese missionaries who by now had succeeded in building up an indigenous group of followers in many of their missions fields including India. Thus by 1870 Assam, was entrusted to the Milanese missionaries and in the same year Central Bengal was raised to the status of a Prefecture with the addition of North Bengal and Assam under Marietti as its first Prefect Apostolic.

The takeover of Assam mission by PIME resulted in the visit of Paride Bertoli, representative of Marietti in 1871 and on his return, Broy was sent to Assam in 1872, as a resident missionary. Unlike what was expected by him his arrival was not without problems and with not even a roof over his head, he was forced to plead to his Superior for help but instead of any assistance Broy was advised by Marietti to turn to the Superiors of Colocero in Italy for permission to collect funds from benefactors in Milan. Till then Broy had to put up in a temporary room offered by Mr. Nelson a Scottish Catholic.

After many repeated attempts failed Broy not only turn to his Superior at Colocero but also toured Assam extensively to collect funds as it was evident in one of his letter to his Superior dated $15^{\text {th }}$ February 1873 , where Broy stated that the extensive tour of Assam had affected not only his health but also his pastoral care. With no assistance and help Broy even sought permission to leave Assam and be appointed to teach English to the mission students at San Colocero. He was told to stay on.

In another letter dated $1^{\text {st }}$ November 1877 Broy reported to the Cardinal Prefect of how "After six long years of stay in Assam he had been able to construct a Chapel and a Mission house at Nowgong at the cost of 5000 francs and 1050 each.” The Chapel constructed in honour of St. Joseph became the first Catholic Church in Assam. In addition Broy managed to raise a second house and a Chapel at Nowgong in 1875 to be followed by the opening of a third station in Shillong in 1876 which was partly a Chapel and partly a house for him to stay during his visit. Two more stations were founded by Fr. Broy, one at Dhubri, the main town of Goalpara district and the other at Dibrugarh. Due to lack of funds no construction was under taken in these stations.

Indeed the field of work and task entrusted to Broy was very large and he was often challenged by the fact that he had to reach out to his flocks scattered all over Assam and numbering not less than 196 according to 1877 census. His task was made all the more difficult due to the distances and lack of adequate means of communication. To quote Matthew Mutthumana, "Quite often he had to walk for many days to visit one single community. Only to a few places it was possible to travel by steamboats or by train. Occasionally he travelled by bullock-cart or on the back of an elephant." Very often Broy would visit Dibrugarh, Dum Duma (14 miles from Dibrugarh) and Margherita a distance of 30 miles on the same day and under very difficult circumstances. Though Broy often complaint and asked for more personnel, he was denied and no one was sent on the ground of shortages of missionaries.

\section{Lack of support}

Since Broy had to look after the five main stations, to tour the length and breadth of Assam meeting the spiritual needs of his flocks hence from human point of view it seems to be quite impossible to think of evangelization. No doubt great effort, much time, energy and perseverance were needed to have direct contact with the people of the Assam valley majority of whom were Hindus, but above all he would have to master their language in order to consolidate mission work. In a letter to his Superior in Milan written in July, 1883 Broy himself admitted that, "There are no conversions among the Tribal people here for lack of missionaries and means of support. We can only hope for better times and that one day they may become civilized and Christian". Since it had often been argued that if Broy had more personnel and better resources his contribution to the Assam mission and to the tribals of the area would have been more momentous and lasting, hence the question 
that arises is whether the fate of the Catholic Church in North East India would have been different had Broy been provided with all the means that was required for a church to thrive.

Another project which was very dear to Broy's heart was his commitment to setup a school and an orphanage in Gauhati and though he tried very hard to convince his superiors to support him in this project, it was turn down and hence failed to get started. At a time when the Baptist and the Walsh Presbyterian had made much head way by adopting education as a medium of evangelisation, the Catholics under the Milanese missionaries in Assam failed to take advantage of an investment worthy a cause.

What prevented Broy from getting assistance in his vast 'vineyard' or what were the great setbacks to the Catholics in North East India during Broy's eighteen long years of staying in Assam. One convincing interpretation indicates that Broy was neglected by his Superior Marietti because he was not satisfied with Broy's earlier tenure in Bengal as Procurator, his unpopularity among his colleagues in the mission of Central Bengal and moreover due to his "unwillingness to initiate any new apostolate among the native tribes of Assam." All this made conversion to Christianity quite negligible. No doubt the main objective of the Prefect Apostolic of Central Bengal, when they took over Assam, was conversion of the indigenous people of Assam, to encounter the serious threat of Protestantism. That his superior were unwilling to assist Broy speaks volumes about the kind of differences that existed within the Society though fully aware of the fact that extra men and resources were required for the Assam mission "since the Assamese were not as open to conversion as were the animist hill tribes."

The fact that Marietti himself who visited Assam and Shillong in 1873, delayed the project of building a residence for his missionaries because of the uncertainty regarding their ecclesiastical jurisdiction over Shillong also undermined missionary work in the area which otherwise could have made a difference to the history of Catholicism in the region. In his article entitled "Roman Catholicism in the Khasi Hills 1871 - 1890" (Proceedings of NEIHA - 1987), George Kottupallil argued extensively that the woes of Broy were made more difficult with the claims and counter claims of the Benedictines and Milanese missionaries for Shillong to be part of their ecclesiastical jurisdictions. This eventually affected Broy's commitment to reach the Khasis with the Gospel-which only supported what Broy himself had claimed "that his presence and particularly his Apostolate in Shillong were not appreciated by the Dacca missionaries," thus forcing him to take very little or no interest in the hills which resulted in the neglect of work among the Khasis.

Fr. Broy's long stay in Assam without any break affected his missionary zeal and health and at times difficulties, annoyances and trials did compel him to swerve from his resolve. In his own words "Even years in Assam under privation of every kind, is enough to try any one beyond his strength". On many occasion he had pleaded to return to Italy to look after his ailing sister but it was denied. It was only in April 1879 that due to the departure and illness of several missionaries, Broy was recalled to Krishnagar to assist in the mission work there. However, within five months his substitute in Assam, Fr. Tanganelli had to be repatriated back to Bengal on account of depression and mental illness for which Broy had to return back to Assam in December 1879.

\section{Conclusion}

The lack of spiritual help and fraternal fellowship from his confreres and superiors caused Broy considerable suffering. In the spring of 1884 Broy again pleaded with his superior that he return to Italy. His health, however, prevented him from undertaking the journey and instead went to Sanada to rest. He returned to Assam and continued to work there till 1890 when Broy himself handed over Assam to the newly founded German Society of Catholic Education or Salvatorians. After leaving Assam in 1890 Broy never returned to his native land Italy, instead he decided to join the Jesuit order of Calcutta. He passed away in 1900 in Barrackpore.

Though Broy's mission was one which was marred by many controversies and difficulties yet his greatness as a missionary consisted in the dedication, love and regularity with which he did the ordinary things of life. Pioneering no doubt calls for initiative, daring dedication and great capacity for sufferings and Broy no doubt with remarkable strength and courage offered his complete service to the mission in Assam for eighteen long years, with no one by his side. This was a great service to the Church and though he may be considered as a missionary without a formal mission, he has gone down in the annals of Christianity in North East India as a pioneering missionary. Appreciating the service of this Italian priest, Bishop Thomas Menamparampil writes:

Fr. Jocopo Broy is the most outstanding figure in the early history of the church in Assam ...The work of catering to the needs of existing communities in itself was so great that he was unable to launch into the work of expansion ... He felt terrible alone ... But he did not move from his post until he had handed over the charge to reliable hands. Assam owes a great debt gratitude to Fr. Jocopo Broy. 


\section{References}

[1] George Kottuppallil, History of the Catholic Mission in Central Bengal 1855-1886, Vendrame Institute, Shillong, 1988, p.65.

[2] Sebastian Karotemprel, (Revised Ed). The Catholic Church in North East India 1890-1915, Becker Institute, Sacred Heart Theological College, Shillong, 2007, p.139.

[3] Matthew Muttumana, Christianity in Assam and Interfaith Dialogue, Indore, 1984, p.69.

[4] Sebastian Karotemprel (ed.), Op.cit, p.146.

[5] Sebastian Karotemprel (ed.), The Catholic Church in North East India 1890-1990, Vendrame Institute, Shillong, 1993 , p.34.

[6] George Kottuppallil, Op.cit., p.208

[7] George Kottuppallil, 'Roman Catholics in Khasi Hills (1877-1890)', NEIHA Proceeding, 1982, p.332.

[8] Sebastian Karotemprel, (Revised Ed), op.cit. p.147.

[9] O.Paviotti, The Work of His Hands, Don Bosco Press, Shillong, 1987, p.6. 